\title{
Effective Atomic Number and Electron Density Determination of Some Amino Acids by Using Scattering Intensity Ratio of $59.54 \mathrm{keV}$ Gamma Rays
}

\author{
Ahmet TURŞUCU \\ Sirnak University, Faculty of Engineering, Department of Energy Systems Engineering, Şırnak, \\ Turkey \\ Geliş / Received: 22/06/2018, Kabul / Accepted: 16/10/2018
}

\begin{abstract}
In this study the specific atomic arguments have been determined for F-Glycine $\left(\mathrm{C}_{2} \mathrm{H}_{5} \mathrm{O}_{2} \mathrm{~N}\right)$, Alenine (L, D) $\left(\mathrm{C}_{3} \mathrm{H}_{7} \mathrm{O}_{2} \mathrm{~N}\right)$, Leucine (L, D) $\left(\mathrm{C}_{6} \mathrm{H}_{13} \mathrm{O}_{2} \mathrm{~N}\right)$, L-Proline $\left(\mathrm{C}_{5} \mathrm{H}_{9} \mathrm{O}_{2} \mathrm{~N}\right)$ amino acids. The calculation procedure of the experimental values of atomic parameters was carried out by using scattering intensity ratios of $\gamma$-rays. These $\gamma$-rays were obtained from $5 \mathrm{Ci}^{241} \mathrm{Am}$ annular radioactive source. In traditional studies, these arguments were determined by transmission technique. The scattered $\gamma$-rays were counted by using an HPGe semiconductor detector. Our detecting system was connected to a separate amplifier and an Accuspec card. Theoretical values of related atomic parameters for amino acid targets were calculated and cross checked with our experiential values. Our deliberated values are in good concordance with theoretical calculations.
\end{abstract}

Keywords: Amino Acids, Electron Density, Effective Atomic Number, Rayleigh to Compton Scattering Intensity Ratios

\subsection{4 keV Enerjili Gama Işınlarının Saçılma Şiddet Oranlarını Kullanarak Bazı Aminoasitlerin Etkin Atom Numarası ve Elektron Yoğunluklarının Belirlenmesi}

$\ddot{O} \mathbf{z}$

$\mathrm{Bu}$ çalış̧mada $\mathrm{H}, \mathrm{C}$, N ve $\mathrm{O}$ içeren F-Glycine $\left(\mathrm{C}_{2} \mathrm{H}_{5} \mathrm{O}_{2} \mathrm{~N}\right)$, Alenine (L, D) $\left(\mathrm{C}_{3} \mathrm{H}_{7} \mathrm{O}_{2} \mathrm{~N}\right)$, Leucine $(\mathrm{L}, \mathrm{D})$ $\left(\mathrm{C}_{6} \mathrm{H}_{13} \mathrm{O}_{2} \mathrm{~N}\right)$, L-Proline $\left(\mathrm{C}_{5} \mathrm{H}_{9} \mathrm{O}_{2} \mathrm{~N}\right)$ aminoasitlerinin etkin atom numaras1 ve elektron yoğunlukları belirlenmiştir. Diğer çalışmalardan farklı olarak, ilgili parametreler gamma ışınlarının saçılma şiddet oranları kullanılarak tespit edilmiş̧ir. Geleneksel uygulamalarda soğurma tekniği kullanılarak tespitler yapılmaktadır. 5 $\mathrm{Ci}$ güce sahip ${ }^{241} \mathrm{Am}$ radyoaktif halka izotop kullanılarak gamma ışınları elde edilmiştir. $5 \mathrm{Ci}^{241} \mathrm{Am}$ halka kaynaktan yayınlanan gamma ışınları hedeften saçılmıştır. Saçılan fotonlar HPGe yarıiletken dedektör kullanılarak sayılmıştır. Dedektör sistemine bağlı yükseltici ve Accuspec kartı bulunmaktadır. Teorik değerler, deneyler sonucunda elde edilen değerler ile karşılaştırılmıştır ve uyum içinde oldukları tespit edilmiştir.

Anahtar Kelimeler: Aminoasitler, Elektron Yoğunluğu, Etkin Atom Numarası, Rayleigh Saçılma Şiddetinin Compton Saçılma Şiddetine Oranı

\section{Introduction}

In recent years researchers have obtained important atomic arguments related with elements, biological specimens, chemical compounds, thin films, alloys and other scientific specimens by using $\mathrm{x}$-ray spectroscopy technique. (Eritenko et al. (2018), Hosami and Badiger (2018), Baris et al. (2018), Akman et al. (2018), Kong et al. (2018). This technique is a non-destructive and practical way to determining atomic parameters. Some of these parameters are intensity ratios of atomic levels, mass attenuation coefficients, effective atomic number, level widths, electron density and vacancy transfer probabilities of target substances. In experimental procedure, researchers have used photon scattering and photon transition techniques to obtain the atomic parameters of selected targets. The transition geometry is supplying us to determine attenuation constants of target substances. This technique has widely used in 
determination of mass attenuation coefficients of shielding substances. In addition to this determination method we can also use the scattering intensity ratios of photons. This method had also supplied us characteristic properties of related target by using target spectrum. In this work we have used the scattering intensity ratios of Compton and coherent spectrums. The effective atomic number and the effective electron densities of amino-acids have calculated. Determination of the effective atomic number has increasingly studied in recent years. Some researchers have carried out their studies on this area by using scattering intensity ratios. Singh et al. (2010a) have deliberated the effective atomic numbers of scientific (oxides of lanthanides and alloys of lead and tin at known composition) and biological specimens (iodine content of tissues) using scattering intensity ratios of $145 \mathrm{keV}$ gamma rays. Singh et al. (2010b) have determined the effective atomic number of scientific specimens by scattering intensity ratios of $59.54 \mathrm{keV} \gamma$-rays. There are some points should consider to determination process of the effective atomic number by scattering intensity ratio method. One of these points is thickness of specimen. Increasing thicknesses are creating multiple scattering centers on the target. Therefore, the multiple scattering densities are increases with the increasing thickness Singh et al. (2009) have determined the effect of multiple scattering on the effective atomic number. The effective atomic number of complex substances using Rayleigh to Compton scattering of $279 \mathrm{keV}$ gamma rays have investigated by Singh et al. (2007) In addition to these studies, some researchers have studied the effective atomic number determination with dissimilar specimens and dissimilar energy regions. Muhadar and Sahota (1988) have studied the effective atomic number of 12 dissimilar soil specimens in 10-5000 keV energy regions. They have seen that the effective atomic numbers of complex substances were changed with increasing or decreasing values of incident energy. Morteza et al. (2013) have studied to determine the effective atomic number and electron concentration of bacteriorhodopsin and its comprising amino acids in the energy rate $1 \mathrm{keV}-100 \mathrm{GeV}$. The bacteriorhodopsin (BR) is used in fabrication procedure of micro/nano devices and sensors. This functional protein is sensitive to radiation and widely used in radiation sensor interfaces. Elmahroug et al. (2013) have studied to determine the total mass attenuation constants, effective atomic numbers and electron concentration for dissimilar shielding substances. They carried out this study with the help of transmission geometry. In this technique The Beer-Lambert's law was used for determining the mass attenuation constant of matter. This work has aimed to determination of atomic parameters of some amino-acids (F-Glycine $\left(\mathrm{C}_{2} \mathrm{H}_{5} \mathrm{O}_{2} \mathrm{~N}\right)$, Alenine $(\mathrm{L}, \quad \mathrm{D}) \quad\left(\mathrm{C}_{3} \mathrm{H}_{7} \mathrm{O}_{2} \mathrm{~N}\right)$, Leucine $(\mathrm{L}, \quad \mathrm{D})$ $\left(\mathrm{C}_{6} \mathrm{H}_{13} \mathrm{O}_{2} \mathrm{~N}\right)$, L-Proline $\left.\left(\mathrm{C}_{5} \mathrm{H}_{9} \mathrm{O}_{2} \mathrm{~N}\right)\right)$. For this purpose, we have prepared sample pellets that has pressed up to 10 tones. The effective atomic numbers and effective electron density of these samples were not determined in past works by using this scattering method.

\section{Material and Method}

\subsection{Experiential Details}

In this work, firstly we have aimed to determining the effective atomic numbers of selected amino acid specimens. Determination of the effective atomic numbers is based upon scattering intensity ratios of related specimens. For this purpose, we have used $5 \mathrm{Ci}^{241} \mathrm{Am}$ annular source as an exciter and HPGe semiconductor detector for counting the dispersed photons. Fig. 1 shows the experiential setup that used in this work. 


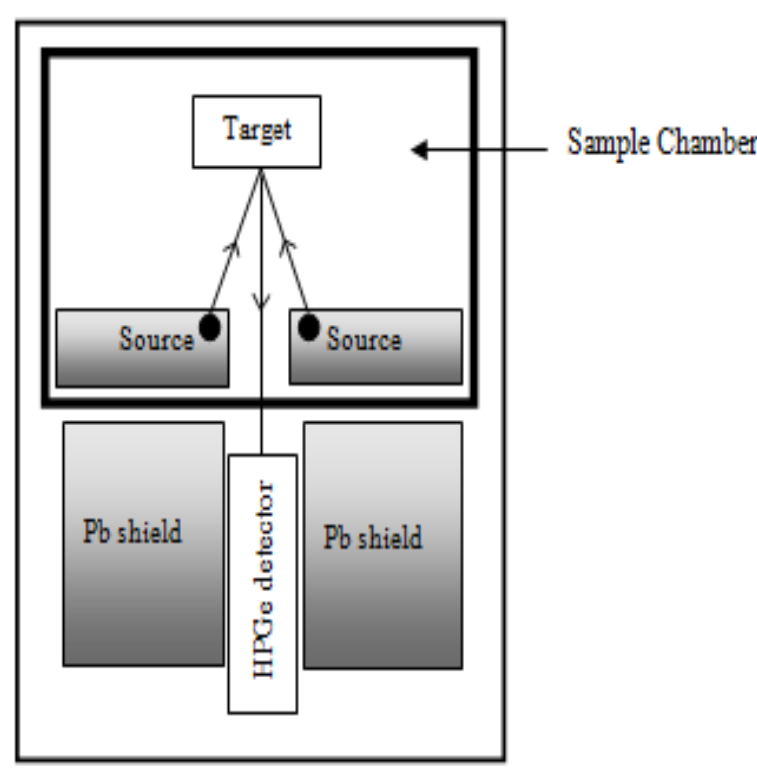

Figure 1. Experiential setup (radius of collimator is $0,53 \mathrm{~cm}$ ).

The thickness of amino acid targets was varying from 0,049 to $0,202 \mathrm{~g} / \mathrm{cm}^{2}$. In experiential procedure the studied specimens and their chemical components were FGlycine $\left(\mathrm{C}_{2} \mathrm{H}_{5} \mathrm{O}_{2} \mathrm{~N}\right)$, Alenine (L, D) $\left(\mathrm{C}_{3} \mathrm{H}_{7} \mathrm{O}_{2} \mathrm{~N}\right)$, Leucine (L, D) $\left(\mathrm{C}_{6} \mathrm{H}_{13} \mathrm{O}_{2} \mathrm{~N}\right)$, LProline $\left(\mathrm{C}_{5} \mathrm{H}_{9} \mathrm{O}_{2} \mathrm{~N}\right)$ respectively. The experiential setup was in inspection by the Genie-2000. The multi-channel analyzer (MCA) was used in 1024 channel option. We have used 1024 channel possibility of MCA because, we don't need to determine the characteristic spectrum of samples. The detector has collimated with $\mathrm{Pb}$ shield to avoiding unwanted spectrums. The $\mathrm{Pb}$ shield have attenuated the unwanted spectrums. For best counting rates from detector we were set the time constant of Ortec model 472 amplifiers to $6 \mu \mathrm{s}$. Collected spectrums have investigated by the Origin 7.5 software program.

\subsection{Measurements of Effective Atomic Number}

Photons have widely used in application of spectroscopy experiments. In these experiments, three dissimilar situations may happen when the photon have impinged with substance atoms. Scattering of the photons are one of them. The two other process have called attenuation and pair production. The pair production process is occurring in high energy scale of photons about $1.02 \mathrm{MeV}$. According to the dispersed energies of photons, the scattering process has divided into two. If the photon has same energy after the collision, this collision has named as a Rayleigh scattering. The probability of Rayleigh scattering has given by

$$
\frac{d \sigma_{R}}{d \Omega}=\frac{r_{0}^{2}}{2}\left(1+\cos ^{2} \theta\right)|F(q, Z)|^{2}
$$

where $q$ describing the momentum transferred to the electron, $F(q, Z)$ is the atomic form

factor, $r_{0}\left(=2.8179 \times 10^{-15} \mathrm{~m}\right)$ is the classical electron radius and $\theta$ is the scattering angle. When the incident and dispersed photon have dissimilar energies, this scattering is called as Compton scattering. The Compton scattering probability is provided by Klein-Nishina equation and given as

$$
\left(\frac{d \sigma}{d \Omega}\right)_{K N}=\frac{1}{2} r_{0}^{2}\left(\frac{E}{E_{0}}\right)^{2}\left(\frac{E_{0}}{E}+\frac{E}{E_{0}}-\sin ^{2} \theta\right)
$$

here $E$ and $E_{0}$ dispersed and incident photon energies respectively. Ratio of the $\mathrm{R} / \mathrm{C}$ is given as

$R=\left(\frac{d \sigma}{d \Omega}\right)_{R} /\left(\frac{d \sigma}{d \Omega}\right)_{a C} \propto \frac{|F(q, Z)|^{2}}{S(q, Z)}$

here $(d \sigma / d \Omega)_{a C}$ is atomic Compton scattering cross-section that occur from scattering by bound electrons. The atomic Compton scattering cross-section given as

$$
\left(\frac{d \sigma}{d \Omega}\right)_{a C}=S(q, Z)\left(\frac{d \sigma}{d \Omega}\right)_{K N}
$$

Theoretical calculation data for $\mathrm{R} / \mathrm{C}$ from arguments of $F(q, Z)$ and $S(q, Z)$ has created by Hubbell and Overbo (1979). 
The $R$ value, which is directly related to the atomic number of elemental interest, is computed via weighted atomic proportions of elements by using $F(q, Z)$ and $S(q, Z)$.

$$
R=\left(\frac{d \sigma}{d \Omega}\right)_{R} /\left(\frac{d \sigma}{d \Omega}\right)_{a C} \propto \frac{\sum_{j=1}^{n} a_{j}{ }^{a t}\left|F\left(q, Z_{j}\right)\right|^{2}}{\sum_{j=1}^{n} a_{j}{ }^{a t} S\left(q, Z_{j}\right)}
$$

here $a_{j}^{a t}$ describes atomic proportions and calculated by $W_{j}$ and the atomic mass $A_{j}$ of the $j$ th element as

$$
a_{j}{ }^{a t}=\frac{\left(W_{j} / A_{j}\right)}{\sum_{j}\left(W_{j} / A_{j}\right)}
$$

The effective atomic number was calculated with the use of above-mentioned expressions.

\subsection{Measurement of Photo-Peak Areas}

Recorded amino acid spectrums were in superimposed continuum during the experiential procedure. To eliminate characteristic spectrum from superimposed spectrum we were used following formula

Peak area $=\sum_{i=A}^{B} C_{i}-(B-A) \frac{C_{A}+C_{B}}{2}$

where the related region of photo-peak channels are specified by $A$ and $B$, net counts at the photo-peak region specified by $C_{A}$ and $C_{B}, C_{i}$ is the sum of counts between the limits $A-B$. The self-absorption correction of air and specimen, photo-peak effectiveness of the HPGe detector was applied to all deliberated dispersed spectra in following relation

$$
N_{\text {actual }}=\frac{N_{o b s}}{\varepsilon_{\gamma} \beta_{\gamma a} \beta_{\gamma t}}
$$

here $N_{o b s}$ is the counted total dispersed photon intension under the related scattering peak; $\beta_{\gamma a}$ is the air absorption adjustment constant between the specimen and the counter system; $\beta_{\gamma t}$ is the self-absorption adjustment constant of dispersed photons from specimen; and $\varepsilon_{\gamma}$ is the photo-peak effectiveness of the counter system for dispersed photons. The determination of the self-absorption adjustment constant has carried out by using Weyrich (1975) equation.

$\beta=\frac{1-\exp \left[-\left(\mu_{1}+\mu_{2}\right) d\right]}{\left(\mu_{1}+\mu_{2}\right) d}$

here $\mu_{1}$ and $\mu_{2}$ are describes the adsorption constant of incident and dispersed photons respectively and $d$ is the specimen mass density. The graph of the HPGe semiconductor detector photo-peak effectiveness is deliberated experientially by given relation

$\varepsilon_{\gamma}=\frac{A_{c}}{N_{0} p_{\gamma} e^{-\lambda t}}$

where $A_{c}$ is net photo-peak area, $N_{0}$ the activity of ${ }^{241} \mathrm{Am}$ source, $p_{\gamma}$ the unconditional gamma ray propagation contingency, $\lambda$ is the deterioration constant and $t$ the elapsed time since standardization. The radioactive properties of source (emission properties and energies) that used in experiential procedure have taken from Firestone and Ekström (2004).

\subsection{Measurement of Fit Graph}

The obtained values of Rayleigh and Compton scattering intensity ratios from experiential procedures for dissimilar specimens of known atomic number is aforethought as a function of atomic number and is given in Fig. 2. 


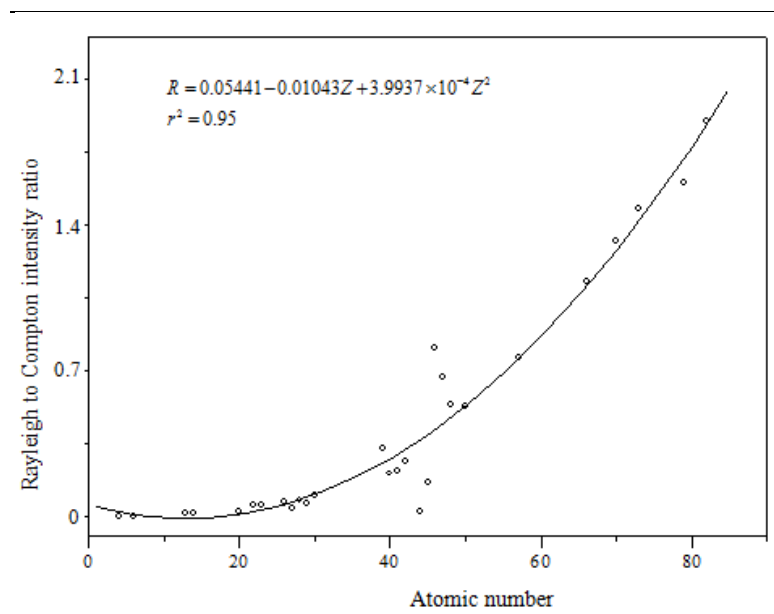

Figure 2. Rayleigh to Compton scattering intensity as a function of atomic number.

The rigid graph describes the best-fit graph through experiential data points equal to the intensity ratios of Rayleigh to Compton scattering. The equality for the best-fit graph was obtained in our previous paper Demir and Turşucu (2013) and given by following relation

$$
R=0.05441-0.01043 Z+3.9937 \times 10^{-4} Z^{2}
$$

The scattering spectra of the amino acids and their intensity ratios were calculated. Then the calculated values of scattering intensity ratios $\mathrm{s}$ were evaluated from best-fit graph of equation (11). The effective atomic number of amino acids was deduced with this technique. The mass attenuation constant and electron concentration were calculated after this separation. The effective atomic number and other calculated arguments were evaluated theoretically from ratio of atomic form factor and incoherent scattering function. The present effective atomic number, other experiential values in literature and Rayleigh to Compton dispersed intensity ratios are given in Table 1.
Table 1. Theoretical and Experiential values of effective atomic number.

\begin{tabular}{c|c|c|c} 
& Theoretical & Experimental & $\%$ Error \\
\hline F-Glycine & 6.653 & 6.808 & 2.323 \\
\hline L-Alenine & 6.518 & 6.989 & 7.231 \\
\hline D-Alenine & 6.518 & 6.853 & 5.143 \\
\hline D-Leucine & 6.859 & 6.746 & 1.658 \\
\hline L-Leucine & 6.859 & 6.598 & 3.819 \\
\hline L-Proline & 6.406 & 6.803 & 6.207 \\
\hline
\end{tabular}

Also, theoretical values of the effective atomic numbers of amino acids have given Table 2.

Table 2. Theoretical and Experiential values of electron concentration $\left(\times 10^{23}\right)$.

\begin{tabular}{l|c|c|c} 
& Theoretical & Experimental & \% Error \\
\hline F-Glycine & 3.706 & 3.792 & 2.269 \\
\hline L-Alenine & 3.832 & 4.109 & 6.743 \\
\hline D-Alenine & 3.832 & 4.029 & 4.891 \\
\hline D-Leucine & 4.364 & 4.291 & 1.687 \\
\hline L-Leucine & 4.364 & 4.197 & 3.971 \\
\hline L-Proline & 4.119 & 4.375 & 5.844 \\
\hline
\end{tabular}

The present experiential calculation values of atomic form factors and incoherent scattering function values have given in Table 3.

Table 3. Calculated values of atomic form factors and incoherent scattering Functions.

\begin{tabular}{c|c|c} 
& $\mathbf{F}(\mathbf{x}, \mathbf{Z})$ & $\mathbf{S}(\mathbf{x}, \mathbf{Z})$ \\
\hline F-Glycine & 0.000615998 & 1.3339598 \\
\hline L-Alenine & 0.000317923 & 1.3451613 \\
\hline D-Alenine & 0.000317923 & 1.3451613 \\
\hline D-Leucine & 0.000615998 & 1.3339598 \\
\hline L-Leucine & 0.000615998 & 1.3339598 \\
\hline L-Proline & 0.000257192 & 1.3546709 \\
\hline
\end{tabular}


The total uncertainty was arising from dissimilar arguments in the experiential procedure. These uncertainties are the peak area evaluation (1.49-3.51\%), the mass thickness of selected target (1.45-3.20\%), the effectiveness of related photo-peak (1.10-2.04 $\%)$ and statistical error $(<1.00 \%)$. The calculated total uncertainty in the experiential arguments have calculated between 2.58-5.35 $\%$.

\section{Findings}

In this paper, the effective atomic numbers and the effective electron densities of amino acids were determined via measurements of Rayleigh and Compton scattered photon intensities by using $59.54 \mathrm{keV} \gamma$-rays. For this purpose, we have created a fit graph. This fit graph was constituted with the Rayleigh and Compton scattering intensity ratios of known pure element samples (Be, C, Al, Si, Ca, Ti, $\mathrm{V}, \mathrm{Fe}, \mathrm{Co}, \mathrm{Ni}, \mathrm{Cu}, \mathrm{Zn}, \mathrm{Y}, \mathrm{Zr}, \mathrm{Nb}, \mathrm{Mo}, \mathrm{Ru}, \mathrm{Rh}$, $\mathrm{Pd}, \mathrm{Ag}, \mathrm{Cd}, \mathrm{Sn}, \mathrm{La}, \mathrm{Dy}, \mathrm{Yb}, \mathrm{Ta}, \mathrm{Au}$ and Pb). Their thickness was varying from 0.022 to $0.865 \mathrm{~g} / \mathrm{cm}^{2}$. The dispersed spectra of these targets were recorded for period of 360061200 s. Background spectra was recorded at same period and subtracted from characteristic spectrum to eliminate effects of cosmic rays and any other adverse effects on the spectrum.

\section{Result and Discussion}

The effective atomic number, effective electron concentration, incoherent scattering functions and atomic form factors have calculated for L- and D- isomers of some selected amino acids. The present calculations of the effective atomic number, effective electron concentration, incoherent scattering functions and atomic form factors will shed light on radiation physics, biological and medical applications. The experiential calculations have showed that the effective atomic number, effective electron concentration, incoherent scattering functions and atomic form factor values are in good agreement with theoretical values. Unlike other works, this study has carried out by using scattering intensity ratios $\mathrm{s}$. Therefore, more experiential studies should be done to increase reliability.

\section{Acknowledgement}

This work is supported by Sirnak University Research Fund (BAP), Project no: 2017.03.03.03.

\section{References}

Akman, F., Geçibesler, I.H., Sayyed, M.I., Tijani, S.A., Tufekci, A.R., Demirtas, I. 2018. Determination of some useful radiation interaction parameters for waste foods. Nuclear Engineering and Technology, 50, 944-949.

Baris, T., Tongucb, Arslana, H., Al-Buriahi, M.S. 2018. Studies on mass attenuation coefficients, effective atomic numbers and electron densities for some biomolecules. Radiation Physics and Chemistry, 153, 86-91.

Demir., D, Turşucu, A. 2013. Measurement of the effective atomic number of $\mathrm{Fe}_{\mathrm{x}} \mathrm{Cr}_{1_{-} \mathrm{x}}$ and $\mathrm{Fe}_{\mathrm{X}} \mathrm{Ni}_{\mathrm{x}}$ alloys using scattering of gamma rays. Journal of Alloys and Compounds, 581, 213-216.

Elmahroug, Y., Tellili, B., Souga, C. 2015. Determination of total mass attenuation constants, effective atomic numbers and electron densities for different shielding materials. Annals of Nuclear Energy, 75, 268.

Eritenko, A.N., Tsvetiansky, A.L., Pole, A, A. 2018. Analytical dependence of effective atomic number on the elemental composition of matter and radiation energy in the range $10-1000 \mathrm{keV}$. Nuclear Instruments and Methods in Physics Research B, 414, 107-112.

Firestone, R.B., Ekström, L.P. 2004. http://ie.lbl.gov.toi/ WWW Table of Radioactive Isotopes, Version 2.1, January. 
Hosamani, M.M., Badiger, N.M. 2018. Determination of effective atomic number of composite materials using backscattered gamma photons - A novel Method. Chemical Physics Letters, 695, 94-98.

Hubbell, J.H., Overbo, I.J. 1979. Relativistic atomic form factors and photon coherent scattering cross-section. Journal of Physical and Chemical Reference Data, 8, 69.

Kong, X., Dang, L., Shao, X., Yin, L., Ji, Y., 2018. Rapid method for determination of $90 \mathrm{Sr}$ in biological samples by liquid scintillation counting after separation on synthesized column. Journal of Environmental Radioactivity, 193-194, 15-19.

Morteza, A., Nolan, L., John, T., Yeow, W. 2013. Effective atomic numbers and electron densities of bacteriorhodopsin and its comprising amino acids in the energy range $1 \mathrm{keV}-100 \mathrm{GeV}$. Nuclear Instruments and Methods in Physics Research Section B: Beam Interactions with Materials and Atoms, 300, 30.

Muhadar, G.S., Sahota, H.S. 1988. Effective atomic number studies in different soils for total photon interaction in the energy region 10-5000 kev. Applied Radiation and Isotopes, 39, 1251.

Singh, M. P., Singh, B., Sandhu, B.S. 2007. Measurement of the effective atomic number of composite materials using Rayleigh to Compton scattering of 279 keV gamma rays. Physica Scripta, 76, 281 .

Singh, M. P., Singh, B., Sandhu, B.S. 2009. Investigations of multiple scattering of $320 \mathrm{keV}$ rays: a new technique for assigning effective atomic number to composite material. Physica Scripta, 79, 035101.

Singh, M.P., Sharma, A., Singh, B., Sandhu, B.S. 2010a. Non-destructive evaluation of scientific and biological samples by scattering of $145 \mathrm{keV}$ gamma rays. Radiation Measurements, 45, 960.

Singh, M. P., Sharma, A., Singh, B., Sandhu, B.S. 2010b. A non-destructive technique for assigning effective atomic number to scientific samples by scattering of $59.54 \mathrm{keV}$ gamma photons. Nuclear Instruments and Methods in Physics Research Section A: Accelerators, Spectrometers, Detectors and Associated Equipment, 619, 63.

Weyrich, W. 1975. The electron momentum distribution in solidpotassium fluoride, studied by Compton scattering. Berichte der Bunsengesellschaft für Physikalische Chemie, 79, 11-1085. 